\title{
The Migration-Development-Nexus from gender-sensitive perspective: The Case of Colombian Women in Catalonia ${ }^{1}$
}

\author{
El nexo migración-desarrollo desde un \\ enfoque de género: el caso de las mujeres \\ colombianas en Cataluña²
}

\author{
Arantxa Rosa Hüttinger ${ }^{3}$ \\ Fecha de recepción: 20/11/2020 - Fecha de aceptación: 10/12/2020
}

DOI: https://doi.org/10.22490/26655489.4321

\section{Abstract}

This article focuses on analyzing the transnational activities of Colombian women living in Catalonia in order to determine if this migrant collective can be defined as transnational agent of development and social change. The research is based on the theoretical debates held on the Migration-Development-Nexus and the transnational migration paradigm. According to this paradigm, migrants create transnational social fields that link together their society of origin and destination through multistranded relations like the sending of remittance to their families, the creation of businesses and networks or the exchange of ideas and skills. Those elements can thus promote the development in both societies. In order to conduct the research, the article takes two key components into account that are crucial to understand the linkage between migration and development in the Colombian case: a) The armed conflict, that has lead to the forced and voluntary displacement of millions of Colombians as

1 This article is the product of the research "A Gender-based Approach on the Engagement of Migrant Collectives in Development processes: The Case of Colombian Women in Catalonia", presented as Master thesis of the program International Relations, Security and Development at the Universitat Autònoma of Barcelona, Spain.

2 El presente artículo es producto de la investigación "El compromiso de los colectivos de migrantes en el desarrollo desde un enfoque de género: el caso de las mujeres colombianas en Cataluña", presentado como trabajo final del Máster en Relaciones Internacionales, Seguridad y Desarrollo de la Universitat Autònoma de Barcelona. Artículo de investigación científica y tecnológica.

3 Licenciada en Ciencias Sociales por la Universität Augsburg, Alemania. Magíster en Relaciones Internacionales, Seguridad y Desarrollo por la Universitat Autònoma de Barcelona, España. Correo electrónico: huettingerarantxa@gmail.com ORCID: 00000001-7705-7513 
well as the post-conflict settings and their impact in the creation of transnational fields; b) The role that gender affects the situation and condition of migrants, as the Colombian migrant collective is characterized by a high degree of feminization.

Keywords: migration-development-nexus, gender, transnationalism, post-conflict settings, Colombia, Catalonia

\section{Resumen}

El presente artículo se centra en analizar las actividades transnacionales de las mujeres migrantes colombianas que viven en Cataluña, para determinar si este colectivo se puede definir como un actor transnacional de desarrollo y cambio social. Esta investigación está basada en los debates teóricos sobre el nexo migración-desarrollo y el paradigma de la migración transnacional. Según este paradigma, los migrantes crean campos transnacionales que vinculan las sociedades de origen y destino a través de múltiples tipos de relaciones, como el envío de remesas a sus familias, la creación de negocios y redes, o el intercambio de ideas y competencias. Estos elementos pueden fomentar el desarrollo en ambas sociedades. Para llevar a cabo el análisis, se toma en consideración dos componentes claves que son imprescindibles para comprender el nexo entre migración y desarrollo en el caso colombiano: a) el conflicto armado, que ha provocado el desplazamiento forzado y voluntario de millones de colombianos y colombianas, como los escenarios de postconflicto y sus impactos en la generación de procesos y actividades transnacionales; b) cómo la categoría de género afecta las condiciones de la migración y la capacidad de los sujetos de adquirir compromisos en el desarrollo.

Palabras clave: nexo migración-desarrollo, género, transnacionalismo, entornos postconflicto, Colombia, Cataluña

\section{Introduction}

While the Migration-Development-Nexus (shortcut: MDN) has been a heavily discussed topic since the post-war era, academic and political discourse now increasingly acknowledges migrants and diasporas as transnational agents of development. This is the expression of a paradigm stating that migration can lead to beneficial outcomes for both, countries of emigration and 
immigration, through the sending of remittances, the creation of networks and businesses, etc. (Faist Fauser, 2011). Current debates on the MDN have spread to various fields of research and policies. One of those fields with growing attention are violent conflicts as a cause of forced and voluntary migration and the role migrant collectives can play for reconstruction and development in post-conflict settings. Another strand with rising interest deals with the implications gender can have in those processes, as there are always gains and losses expected through migration, but with different consequences for gender roles (Bermudez, 2016).

These two domains come together when turning the view on the case of Colombia. Sadly, the country holds the record for the longest surviving armed conflict in the continent involving left-wing guerrilla groups, right-wing paramilitary groups and state forces. This has lead to massive movements of internal and international migration which has affected different social classes and ethnic groups in an unequal manner. Still, the population of Colombians abroad is very connected within each other and a big proportion is engaged in gaining influence in the recent peace talks (Bermudez, 2016). Another characteristic of Colombian migration its high degree of feminization. Because of this, I want to take the example of Colombian Women residing in the autonomous community of Catalonia in order to analyze their transnational engagement in development processes.

At this point it is important to clarify that the research is adopting a broad and capabilities-focused perspective on the term development, proposed by Amartya Sen. As he defined human development as a process of expanding the people's substantive freedoms, it can take place in various areas - such as education, health, food or housing - as long as there is an enhancement of people's wellbeing and capabilities (Sen, 1999).

To analyze development contributions from a gender sensitive perspective, it is crucial to take into account all "the societal and cultural factors of exclusion and discrimination based on gender in the most diverse spheres of public and private life" (Šribar, 2015, p. 181). Therefore, though 'gender' being a neutral term including all the sexes, gender sensitive approaches refer mainly to instances of structural disadvantages in the positions of women's lives. Applying this notion, the research aims 
to critically point out their situation during the migration process in Catalonia and the challenges they face in order to make contributions to development processes. Hence, the main research questions are formulated as followed:

a. What are the transnational activities conducted by Colombian Women residing in Catalonia?

b. From those contributions, can they be identified as transnational agents of social change and development from a gender sensitive perspective?

\section{Migrants as Transnational Development Agents: The Discursive Evolution}

The linkage between migration and development has been a relevant topic on the political and academic agendas since the 1950 's. The evolution of the theoretical debate can be parted into three main phases, where dominant opinions have been swinging back and forth between Optimism and Pessimism (De Haas, 2012). The first phase was characterized by economic modernization concepts from the post-WWII era, creating a strong development optimism. Public policies emphasized the need of labour force in the North and argued that immigration from the South also fosters development of the country of origin (shortcut: $\mathrm{COO}$ ) through remittance and return migration (Faist, 2008). After the first oil crisis's in 1973, Europe was challenged by massive economic downturns. This is why, according to Faist (2008), in the second phase, a paradigm shift took place towards dependency perspectives, stating that migration is an exploitation mechanism and causes a brain drain effect in the Global South. The pessimism persisted for over two decades, until new empirical works 'rediscovered' the potential positive impacts of migration. Especially a World Bank's publication called 'Workers Remittances' (Ratha, 2003) moved the financial benefits of migration back into the center of international attention. The discovery that remittances have increased abnormally since the 1990's and continuously surpass the total flows of Official Development Aid led to a publication boom and made migration become a regular feature of development-policy debates. However, significance has also started to be given to knowledge transfers and other flows, summarized with the concept of social remittances: The transfer of universal ideas (like human rights, gender equity, etc.), behaviors and identities (Levitt 
and Nyberg-Sørensen, 2004) that directly or indirectly affects development. The current third phase of the MDN is strongly characterized by the transnational migration paradigm, defined as all "the processes by which immigrants forge and sustain multi-stranded social relations that link together their societies of origin and settlement" (Basch, Glick Schiller, and Szanton Blanc, 1994, p. 6). While in the first phase, policy-makers and researchers concentrated on money transfers and return, the new transnational perspective understands that migration leads to the creation of transnational social fields. Those consist of social and symbolic ties, networks and organizations that cut across the border of at least two national states (Faist and Fauser, 2011). Nowadays, there is a broad number of institutions formed by migrants that are included in the concept of transnational spaces, such as hometown associations, migrant business netwoks, epistemic networks of high skilled professionals or ethno-national communties (Faist, 2008).

\subsection{Migration and Development in the Context of Conflict Ridden Societies}

The role of diasporas as development agents in conflict settings is strongly linked with development agencies taking roles in conflict-management since the mid 1990's. It started to be acknowledged that (post-)conflict situations offer opportunities for political, economic or social reforms to change past structures and therefor the need to address them by development cooperation. While before, diasporas formed by conflicts were perceived negatively (e.g. as 'long-distance nationalists'), it is now assumed that diasporas can play an important role in the 'creative destruction' dynamic of conflict', by rebuilding political and economic structures (Van Hear, 2011). One characteristic of diasporas formed by conflicts is that of "mixed migration": Whereas officially, a clear distinction is made between forced and voluntary migration, they can't be separated easily in reality, as those who flee from a country where violence, persecution and discrimination exist, are also likely to escape economic circumstances. According to Van Hear (2011), this variety of factors typically leads to a dispersion of transnational relations and the creation of networks among such dispersed groups. Besides the transfer of economic remittances, there are three types of contributions that can be identified as social remittance within post-conflict 
reconstruction. Philanthropy includes a variety of non-profit activities directed to humanitarian or development projects. In those activities, migrant associations function as messengers between their PO and NGO's, as they have the local knowledge to better target areas in need of development or humanitarian intervention. Moreover, philanthropy can be used to promote political agendas of diasporas. Diasporas are also a source for human capital, which is often required to (re-)staff government positions or development programs. Within the private sector, they count as the firsts to invest in post-conflict countries, combining their cultural expertise and local networks with new knowledge and networks from abroad. However, it can also be a challenge for security and legitimacy of the COO. As they often receive higher salaries due to their international experience, returnees' presence can replicate pre-conflict stratification of skills and class (Brinkerhoff, 2011). Lastly, diasporas can have a significant political influence, as examples like the South African diaspora in the anti-apartheid movement (Faist, 2008) or the Afghan diaspora's inclusion in drafting the 2002 Constitution show. They may influence the international political opinion for the protection of human rights and political freedoms, as well as 'humanise' the foreign policy of their host country. In the $\mathrm{COO}$, they can be supporting the legitimacy of post-conflict governments or funding cultural mechanisms specific to conflict resolution. Moreover, they can have an important role as peace advocates in their homeland by convincing warring parties or their host states to participate in peace negotiations. However, their participation can also present a risk, when 'out of touch' diasporans lobby for policies that hinder sustainable peace, by focusing on retribution and blame (Brinkerhoff, 2011). As presented, engagements by migrants in conflict settings are various and can always have potential positive and negative outcomes. Besides their ideological ideas and the support by states or international agencies, the capacity to receive positive results for reconstruction and development also depends on formal factors within the migration process, such as: A security of their status, income above subsistence level, freedom of speech, space to develop social competences and political literacy (Van Hear, 2011). 


\subsection{The MDN from a Gender Based Perspective}

Until now, gender within the MDN has been related mostly with the participation of women in the global care chains ${ }^{4}$ or transnational motherhood. Consequently, transnationalism of migrant women has been equated with activities on an individual level, mostly through the sending of remittances to their families (Bermudez, 2016). The rise in female international migration led to the discovery that women tend to send remittance in higher amounts than migrant men. Because of this, it is assumed that they are harder workers, act more responsible towards their family and channel remittances more into productive activities for development. This discovery shifted the international view on migrant women from being the "victims of globalization" into "global heroines of social change" (Cuentas and Vera, 2011). The discussion on female migrants as development agents suffers several shortcomings, derived from the homogeneous image drawn upon migrant women. Especially since migration and remittance are assumed to be a new driving factor for development policies, the generalization of women as more empathetic and responsible puts them into a high risk of instrumentalization. Also, the understanding of development hereby is reduced to economic growth, while their contribution to development trough social remittance is barely discussed. Thus, in order to avoid a reproduction of gender strategies, an analysis of the gendered nature of transnational activities is essential to relate migrant practices to their visions on development (Dannecker and Sieveking, 2009). Additionally, there is a need for contextsensitive analysis of female position's in migration processes, as the euphoria of women's contribution trough remittance always measures the numbers, but hardly questions the conditions under which those women are living to be able to send them. The feminist critique to developmentalist thinking therefore argues that, to be a social agent of change, migrant women need to have all their human rights protected and be able to exert their citizenship equally to the conditions and opportunities than local citizens in the country of residence (shortcut: COR) (Cuentas and Vera 2009). One political arena where gender relations have established a strong mainstay, is in conflict and peace. This can be explained by:

4 "A series of personal links between people across the globe based on the paid or unpaid work of caring" (Hochschild, 2000, p. 131) 
a. The impetus of feminism in academia showing that men and women are affected by conflict and participating in peace-reconstruction in different ways.

b. The global human rights movement bringing attention to the effects of conflict-settings on women. Ever since, attempts have been made to involve women officially in peace processes and study their specific vulnerabilities in post-conflict situations. However, gender in conflict studies from the view of migrant associations is hardly considered. Feminist scholars call for more focus on the multiple, heterogenous ways in which transnationalism and conflict settings affect the different genders and their ways of actively participating in those contexts (Bermudez, 2016).

\section{Methodology}

The findings of this research are based on mostly qualitative methods, consisting of:

a. Semi-structured expert interviews

b. Content analysis of websites and some statistical data

c. Review of specialist literature

During the research period, six interviews were carried out with five Colombian women residing in Catalonia and one Spanish expert in development cooperation with women's organizations ${ }^{5}$. Four were conducted face to face, two by Skype. The next step was to transcript the recorded conversations ${ }^{6}$ and to translate the relevant sections from Spanish to English. Finally, the collected data was analyzed after the principles of the qualitative content

5 Register of the interviewed women and their entities: A: M. R. Vásquez; doctor and human rights activist, member of la Colectiva de Mujeres Refugiadas, Exiliadas y Migradas de Colombia en España. Date of conversation: May 8, 2019 B: M. Cabarcas; political scientist and international consultor of human rights. Date of conversation: May 16, 2019 C: Anonym; Mujeres Palante, Date of conversation: June 14, 2019 D: H. Flamtermesky; founder and coordinator of Mujer Diaspora. Date of conversation: June 18, 2019 E: B. Puerto; co-founder of Mujeres Palante, member of la Colectiva de Mujeres Refugiadas, Exiliadas y Migradas de Colombia en España, Foro Internacional de Víctimas and Asociación Minga. Date of conversation: July 2, 2019 F: M. Palomares Arenas, Fundación Calala - fondo de mujeres. Date of conversation: May 15, 2019.

6 Before recording the conversations, all interview partners were to give their permission with a document handed to them explaining the use of the material. 
analysis by Philipp Mayring, a concept of systematic processing of information material. The analysis procedure after Mayring consists of the following steps:

a. Defining the unit of analysis

b. Analysis: Summarization, Explication and Structuring

c. Verification of the established category system on theory and material

d. Interpretation of the results towards the research question

e. Examining validity of the analysis with quality criteria (Mayring, 2015)

\section{Analytical Framework: Colombian Women in Catalonia}

Unfortunately, there is no official census about the overall Colombian migrant community. According to estimations of the Ministery of Foreign Relations, about 4,7 million Colombians, therefore almost $10 \%$ of the whole population, were living abroad in 2012 (Ramírez and Mendoza, 2013). There are past studies stating that Colombian migration has aquired a truly 'global character' due to the multiple migrant destinations and the development of translational links (Guarnizo, 2008) such as: The political rights the Colombian government has granted to it's emigrants, e.g. by letting them elect representatives to the Colombian legislature (Levitt and Nyberg-Sorensen, 2004); the growing dependence on remittance as national income; and many social, cultural, political and economic links between the migrants and their families and communities of origin (Guarnizo, 2008).

\subsection{Colombian Women in Catalonia: Population and Organizations}

According to the National Statistical Institute of Spain, from the 440.197 Colombians residing in Spain, 75.160 were living in Catalonia in 2018. The big majority lives in the province of Barcelona (54.149), followed by Tarragona (9.422), Girona (6.968) and Lleida (4.351). Colombian migration to Spain has been highly characterized by feminization, resulting in 42.703 or $57 \%$ - of the Colombians in Catalonia being women (Instituto Nacional de Estadística, 2019). Therefore, it is not surprising that the majority of Colombians in Spain work in domestic 
service, although they tend to have relatively high levels of education (Bermudez, 2010). A further web search shows that there is a significant number of Colombians participating in migrant organizations. For instance, Colombia's official program for emigrants Colombia Nos Une (shortcut: CNU) lists 22 organizations in Catalonia, from which 19 are located in Barcelona. There are several local and international organizations based in Barcelona, where Colombian women take protagonist roles and get repeatedly mentioned in related studies, such as: Colectivo Maloka, that supports civil society initiatives (especially women peace groups) in Colombia with funding and lobbying activities and is active in making visible gender implications of the conflict. An important feminist local initiative emerged from Maloka is called Mujeres Palante (Women Ahead) (Bermúdez, 2016), an association of immigrant women that became a crucial agent in Catalonia for the accompaniment of migrant women in their first orientation. Another collective with central importance is la Colectiva de Mujeres Refugiadas, Exiliadas y Migradas de Colombia en España (Collective of Refuge, Exile and Migrant Women of Colombia in Spain) with over 12 delegations and one of the biggest in Barcelona. The members - a broad variety of Colombian women ranging from students up to exiled leaders of social movements - auto define themselves as victims of the armed conflict, as peace advocates and as memory maintainers (Source: Interview $A+E$ ). Eventually, there is the initiative Mujer Diaspora, founded in London and later reproduced in Barcelona, Stockholm and Brussels. Before called Truth, Memory and Reconciliation Commission of Women in the Diaspora, it emerged from the necessity of making visible the situation of migrant women both in Colombia as in their new PR. By collecting testimonies of female victims of conflict, Mujer Diaspora counts as innovative tool of psychosocial healing and empowerment of women in the diaspora (Source: Interview D).

\subsection{Transnational Activities by Colombian Women in Spain?}

Colombian migrants occupy the first place when it comes to frequency and total amount of remittances sent from Spain. In 2008, the number of remittance reached 4,84 Mio. US\$, from which $51 \%$ were sent by women (Corporación Humana, 2012). Regarding the use of the transfers, studies assert that most

7 There was no study found that analyzes transnational activities of Colombians in Catalonia only. 
Colombians send remittances in order to sustain their families, to invest in housing or related goods and to save up for the future (Bermudez, 2016).

According to studies on women migrant's involvement in transnational fields (Bermúdez, 2010, 2016), Colombian women in Europe are possessing of strong political capital. Even though especially middle-class women and political activists from Colombia often find themselves in a position of disempowerment in the COR, many are engaged in political and civic initiatives in relation to both, the home and host society. Also, Colombian migrant women have been very active in transnational activities initiated from above. This is explained, on the one side, by the high feminization of migration to Europe and, on the other, that the focus of such programs is mostly associated with traditional female roles: diaspora philanthropy, links to the $\mathrm{COO}$ and migrant needs. Colombian women in the European diaspora further have strengthened efforts to express their own voices and seek roles in the peace building process from exile. Bermúdez shows that the Colombian migrant collective has a political component strongly connected with the commitment to their $\mathrm{COO}$ and their action taken in development processes. In many cases, leaders within diaspora organizations had a political career path previous to emigration, then adding a new political role in the immigration context and, in some cases, also projecting it when returning. Bermúdez (2010) also describes how associations originally dedicated only to political or cultural activities have evolved towards activities to development in Colombia.

Eventually, having collected the available information related to the subject of investigation as foundation for the data collection, the fieldwork is guided by the following subquestions:

a. Organizational Level: What characteristics do organizations Colombian women participate in have in common?

b. Individual Level: What are the conditions of Colombian women during their migration process in Catalonia?

c. Transnational activities to development: How do women migrants contribute to support the development processes - on an organizational and individual level? What are the limits? 
d. Public policies: How are the public policies in Colombia or Catalonia relating to the Colombian migrants? What is expected to empower them more in the future?

\section{Results ${ }^{8}$}

\subsection{Organizational level: common characteristics}

In general, the Colombian migrant collective is extraordinary connected and supportive amongst each other, within and outside of the country. All the Colombian interview partners indicate various links with Colombian, Latin American, Human Rights, women and migration networks in the place of residence (shortcut: PR), the place of origin (shortcut: PO) and also internationally. For instance, in June 2019 the Colombian community organized the event "Serenata de Amor por la Paz" in Barcelona, to collect money for the recuperation of the Cauca river and the affected villages from the Ituango dam crisis. In this philanthropic event, several Colombian and Catalonian organizations $^{9}$ united to organize the concert and send all the profits to the Colombian organization Ríos Vivos.

This strong interrelation is, inter alia, plausible due to the fact that many of their own organizations already have delegations in several places outside of Spain, as it is the case for the Colectiva, Mujer Diaspora and the International Forum of Victims (Fóro Internacional de Víctimas: FIV). Another factor is the commitment of many migrants in various organizations, like in the case of $\mathrm{C}$, founding member of Mujeres Pa'lante, who has a plurality of links to Colombia:

I am active in the observatory for the cohabitation of the indigenous communities. (...) For many years was part of Maloka. And I've always maintained the nexus with many social movements in Colombia

8 As the findings are mainly based on the statements from the expert interviews, there is no claim for completeness and correctness of their opinions. All inserted quotes have been translated by myself from Spanish to English.

9 ColHibri, Asociación pel canvi Social, Pacific y Democratic, Proces Constituient, Convocan Paz a la Calle Bcn, Colectivo Maloka, Mujeres Pa'lante, FIV Catalonia, Ciudadanías por la Paz, Colombia Humana and La Colectiva 
(...) and other Colombian movements abroad. We try to be in contact, support international events, whatever is necessary. (C)

Interestingly, even though Colombian migrants are extremely connected among each other and to their $\mathrm{COO}$, the interview partners argue that it is often complicated to work together due to the high degree of heterogeneity of Colombians. Colombia is characterized by it's diversity of cultures and identities, including Afro Colombian and indigenous, rural and urban, low to upper class people etc. Hence, there are many different people with different necessities and these dynamics are reproduced in the population abroad and their organizations. Interviewee $B$, who has worked for the program $\mathrm{CNU}$ of the Colombian chancellery, tell about her experiences of preparing the "First reunion for the formation of the national committee of the civil society for migration"10:

I've worked with ex-combatants, with paramilitaries, guerrillas, victims of sexual violence - but no, the hardest work I've ever done was trying to work with the Colombians residing abroad. (...) The migrant population is everything: students, people deprived from liberty, indigenous people. (...) And they united all Colombian organizations in the world to collect proposals for peace. This process was I don't want to say a failure, but it was very, very difficult. (...) All the organizations made proposals for health, for education, they talked about remittances, about everything. (B)

\subsection{Conditions during the Migration Process in Catalonia}

As the interview partners argue, it is complicated to give a valid statement about the general position of the Colombian migrant community in Catalonia due to it's strong heterogeneity. However, there are at least three main groups of Colombian women in the region that - despite their strong interconnection have different needs and face different challenges. First, there are the students and academics, a rather young group migrating for reasons of self-development. When deciding to stay permanently,

10 "Primer encuentro para la conformación de la mesa nacional de la sociedad civil para la migración" (CNU, n.Y.) 
they often struggle with accessing the labour market, from the difficulty of validating their titles. Then, there are the refugees and exiles: Many have been politically active in $\mathrm{COO}$ and had to leave Colombia due to threats from paramilitaries or guerrillas. The notable presence of Colombian exiles in this region also has to do with the various political institutions in Barcelona, like the Taula Catalana per la Pau i els Drets Humans a Colómbia or the International Catalan Institute for Peace, who have clear policies of denouncing human rights violations. For instance, two of the interviewees came to Barcelona through a protection program for human rights defenders and later applied for political asylum.

Eventually there are the so-called economic migrants, a larger group who migrated to Spain in order to find working opportunities. According to the interviewees, the first waves of Colombian migration to Spain were characterized by a high proportion of women coming with basic labor qualifications. Their work used to be well received and had a good pay, until the Spanish economic crisis presented a turning point. According to $D$, the crisis hit migrant women by far the hardest, leaving them without economic protection, like unemployment money or pension. This is worrying as many of them were working hard for many years and thus contributed a lot to the Catalan society. Returning to Colombia many times is not an option, as it would require the support from the family, but the migrant usually is the main sustainer. Thus, many Colombians either remigrated to other EU states or stayed to find themselves in precarious situations. As the unemployment rate raised and migration policies in Spain turned more restrictive, a big proportion of Colombian women migrating for economic reasons live here undocumented, by overstaying a tourist visa. Resulting from the interviews, those women get caught in a vulnerable situation because of the Spanish Immigration Law (Ley de Extranjería; shortcut: LEX): With an irregular migrant status, the only option to legalize the stay and get a work permit is usually to apply for 'arraigo social', a type of residence authorization in exceptional circumstances. According to the interview partners, the LEX is discriminating migrants, as it puts them in a situation of no rights. During three years - the minimum time of residence required to apply for the arraigo (Ministerio de Trabajo, Migraciones y Seguridad Social, 2016) -, they stay undocumented and struggle to sustain themselves without access to public services. Additionally, the LEX is harder on migrant women, because their vulnerability exposes them to various types of violence. Victims of sexual assault wouldn't 
denounce the incident at the police, as they would risk expulsion for being undocumented. As also the accreditation of foreign degrees became increasingly difficult, the labour access is very limited and most women don't have other options than working in the domestic or caring sector. These are the jobs that 'no one with full privileges wants to do' $(E)$, as it is very hard and no dignified work. Especially when hired privately, the work schedules can be quite inhumane - 6-7 days, no vacation - and the salary is often lower than the minimum wage. As an internal worker, women are also in risk of isolation, when being the only employee in a house of strangers and not able to have a social life due to the long working hours:

\section{I have known women that live here for $6,7,8$ years and they still don't know the Mediterranean, because they didn't have the time to go to the beach, never. (...) Saving up the last cent, living in precariousness, to send money back home. (A)}

Furthermore, the interlocutors state that for refugees and exiles, the Spanish immigration policies are even more restrictive. During asylum application, they are handed out a 'red card'11, which limits the citizen rights immensely. In the first six months, they are neither allowed to work nor to leave the country for at least five years. It further exposes them to daily discriminations, like when trying to rent a home or open a bank account.

\subsection{Transnational Contributions of Colombian Migrant Women}

From the previous studies it results that remittances have reached enormous importance in Colombia on the macro and micro level, like the following news article section shows:

"According to the World Bank, the Colombians living abroad have sent the record figure of 6.3 billion US\$ in 2018. A 54\% of this population are women, and while the remittance grows more, those women are contributing proportionally to the country's development. The money sent by the mothers, daughters, sisters and aunts

11 'Tarjeta Roja' or 'Documento acreditativo de la condición de solicitante en tramitación de protección internacional' 
living in the foreign helps millions of families in Colombia for basic necessities, like education and health." (Las Americas, 2019, March 7).

The interviewees confirm that the economic contribution of migrant women is an indispensable element for development. In the COR, they contribute to the GDP by making expenditures, paying taxes etc. while the same time, they're sustaining their families in Colombia, by saving up to send money back home. Still, when praising those women's contribution, one cannot disregard that there is an immense lack of visibility regarding the following factors:

a. The profile of migrant women and their living conditions in the COR: Putting remittance in such a positive light makes the difficulties many women experience - e.g. precarious working conditions - in order to send money home invisible.

b. The specific use families back home are making of the transfers: While many migrants live at the minimum subsistence level to save as much money as possible, the value of the money that arrives the families at home is often not understood. The interviewees report from several situations where remittance expenditures go to material luxury instead of productive investments. This lack of education pedagogy can lead to a destruction of families and many women regretting retrospectively to have left the country. Additionally, they are often in a conflict of being a mother from distance. Not being able to be there for their children, makes them desperate to show their love in a different way and accepting the "unproductive" use of their transfers:

"So, if they want the new sneakers, the moms say 'Sure, go buy them', giving little treats to her child to maintain the love. (...) The Colombian state does not see the misery in this situation. The mother must go to a different place on earth to give food to her children. (...) There is a rupture - but it's obligatory to give this love. I say this because I experienced it. It's a condition that doesn't permit parenting, and parenting is a basic need for a healthy society" (E) 
c. How remittance actually could improve the life capacities: There is a broad number of development challenges in Colombia. Most of them are derived from the longlasting conflict that converted the country into a society of inequality and violence. In addition, the increasing presence of transnational companies, exploiting Colombian territories, left many families in precarious situations, forcing them to escape. However, big migration flows combined with the international remittance hype take away the responsibility from the Colombian government, to supply public goods to its people. The migrants, thus, suffer from the pressure of sustaining their families, hidden in the positive image given to them as promoters of development. Meanwhile, the development challenges are so big and numerous, that the situation in the country first needs to change institutionally for remittances being able to do a contribution.

Besides money transfers, other types of transnational activities have been identified, like the organization of philanthropic events and political forums, sensitization work of politicians, etc. In general one can say that in Catalonia, the organized activities of Colombian women migrants have a strong character of political incidence. There is a broad number of auto-organized collectives defining themselves as victims of the armed conflict. This is why here one of the strongest pillar of Colombian women's activities is maintaining the historic memory. There is an impressive amount of people organized, notably in the Colectiva and Mujer Diaspora, in order to make women exile's life stories a part of the history of Colombia. They collect testimonies about what happened to the women during the conflict, why they have left and ultimately, also trying to understand their motives of having stayed silent, in many cases for many years. The members of the Colectiva emphasize the importance of also collecting testimonies from migrants without refugee status, as the waves of labour migration are rooted in the conflict, too. To give an example, the Colectiva conducted a three year lasting project called "MUJ-ERES", using the methodology of theatre as a space of narratives. The project was valued as an important step to make the voices from exile visible. As a result, the Colectiva published the book "Breaking the silence from exile" (2018), where various life stories were captured and delivered to the Commission of Truth in Colombia. 
Moreover, there is a big will to participate in the peace reconstruction process. However, as political actions are more typical in forms of community activism, a network of supportive organizations is crucial for activities of political incidence. For instance, a workshop for Rights, Peace and Gender was organized 2016 in Barcelona by the regional government and civil society organizations such as the FIV and Mujeres P'alante with the aim "of strengthening the social fabric of the Colombian diaspora (...) and promote citizen participation in the building of peace in Colombia from exile." (Bermúdez, 2016, p. 228).

Another way how migrants support the process of social change in Colombia is through maintaining links with returnees. As many of them participate in other organizations when returning, they are fundamental for the extension of networks among Colombians. Often, returnees (like the members of the Colectiva) have undergone an educational process while living abroad in the form of scholarship programs or university enrollments. Back in Colombia, they can help visibilizing the situation of migrants and exiles by participating in negotiation tables. Being the spokeswomen of their organizations when participating in such spaces (e.g. the Commission of Truth), they make sure that the testimonies for historic memory are also coming from abroad and bring in their proposals for public policies. When recalling the definition of social remittance as the transfer of knowledge and universal ideas, it becomes clear that Colombian migrants are contributing massively beyond the economic and political level and addressing different groups of people. For the Catalan population, the Colombian Diaspora always has been the first source of information regarding the armed conflict in Colombia and now in the peace process. Regarding their $\mathrm{COO}$, Colombian migrants transfer important knowledge concerning respectful co-habitation, gender-relations and other social norms difficult to develop within dynamics of inequality and violence. While living abroad, it is likely to give up the influence of racist, classist or sexist thinking, that are possible to occur in stratified, conflict-affected societies:

Those simple ways of living together, even though they might seem to be minimal changes (...) Like transmitting to men that there are other ways to relate with women. Because we have violence very normalized in Colombia, and also disrespect. 
And there is no man who will say to his colleagues to start respecting women. He'd rather say "Well, that's how they are". But, they do not have to continue being like that. (...) If we'd always say that, we would all still live in trees! (A)

One typical feature of social remittance particular for migrant women has to do with their characteristic trait of being more empathetic towards fellow human beings. Women's individual pronounced role of carers is often being replicated on a macro-level, making them take traditional female roles in cooperation programs, such as: philanthropy, community construction, memory collection, etc. The fulfillment of those female roles is of big value for the world's societies, but it is also crucial that women do this work from their own motivation, hence that it is properly valued and not done for the fact of being a woman. Additionally, migrant women are also having an impact with this culture of caring on an individual level, when transmitting their affection as domestic workers: While they are not able to give love to their own family, they can do it for the family they work for and transmit important values of cordiality. Another characteristic of the collective of Colombian women are their strong capacities of resilience and self-organizing, from which they have created an extensive network where different organizations collaborate to support organizations or social leaders in Colombia. Additionally, there is a big engagement in supporting fellow migrant women - regardless of their nationality or ethnic background among Colombian women in Catalonia. Like in the case of Mujeres $P a$ lante, they offer spaces that help immigrant women in their first reception and create networks of mutual support. In May 2019, for instance, Mujeres Pa'lante organized a 'Political Forum for Migrant Women' in collaboration with different collectives in Catalonia, to make proposals for public policies in presence of representatives of the political parties running in the Barcelona city council elections. Some Colombians are also active in syndicates that fight against the slavery like conditions in the caring or cleaning sector (e.g. Las Kellys Barcelona). The interviewees explain this by the women's high degree of consciousness: Due to undergoing the migration process, they can see the cultural differences and inequalities within society, so that also women who before never participated in organizations before start to see the need of organizing themselves and take action against injustice. 
Finally, another form of social remittance from women migrants can be transferred through intercultural exchange. Colombia has a very rich culture concerning their food, music, community dances and general vitality and loving nature, which is one of the factors why there is still a relatively positive image drawn upon the country despite it's violent history. Those cultural assets and values of cohabitation can be transmitted to the Catalan society thanks to migrants - and their children, when attending Catalonian schools.

\subsection{The Public Policies of Catalonia and Colombia -} Requirements for Greater Empowerment

The autonomous community of Catalonia stands out for its strong solidarity towards societies in conflict. Stating that the individual and collective rights are crucial for the transformation of inequalities, the Catalan government applies a gender and human rights approach in their public policies. Therefore, the Catalan Agency of Development Cooperation (ACCD) counts Colombia as one of eleven places of priority for cooperation projects and programs. The cooperation agency also emphasizes the importance of actively including migrants in development processes, for example through co-development strategies (Agència Catalana de Cooperació al Desenvolupament, 2015). Additionally, there is the Department of Global Justice and International Cooperation of the council of Barcelona. Within South America, the agency preferably works in the main cities of Colombia in order to make them major political agents in the peace process. Further, stateless nations and diasporas facing violations of their rights or political persecution are also priority intervention areas (Ayuntamiento de Barcelona, 2018). According to the interviewees, important programs which have been stigmatized or ignored from the the own government were able to survive thanks to the Catalan cooperation. The Catalan policies give a voice to places that are of crucial importance for the coordination of denouncing human rights violations.

However, there are also deficits of the Catalan public policy approaches to migrant collectives. Even though the ACCD emphasizes Co-development as necessary strategies, there are hardly any official co-development projects undertaken since the economic crisis. Furthermore, the funds for development cooperation are often very limited, which generates a big 
competition on scarce resources. This is a delicate situation, as it creates a division between organizations that are not healthy for civil society's empowerment. In addition, the agencies don't tend to pay salaries to the participants. This is disadvantaging migrants who want to be politically active, as it is promoting volunteering, demanding to invest their time and effort without compensations. And ultimately, there's also a lack of specific measurements for economic support of women migrants' projects. As the incubation time for cooperatives of women migrants is usually longer than for local organizations, the funding schemes are usually not profitable enough to make their projects sustainable. Shifting the view on the origin country, there is far less support offered by the Colombian government than from Catalonia. Regarding the before mentioned congressman representing citizens outside of Colombia, according to the interviewees one single person is not enough to represent the numerous population abroad and therefore cannot know their specific needs.

Further, there is the so far most ambitious state initiative for migrants Colombia Nos Une. Launched in 2002 as part of the development plans from the first Uribe administration, CNU's main objectives are to get to know the reality of Colombian migration and to improve the conditions in the host societies, to reinforce migrant's economic, social, political and cultural participation and to create transnational networks (Bermudez, 2016). However, Interviewee B who worked for CNU states that hardly any resources are spent on getting to know the population abroad profoundly. The program therefore serves more to highlight big achievements of Colombians abroad instead of supporting them with funds or put their proposals for public policies into practice. Further, the efforts of political activists tend to be recognized even less, as exiles represent a threat to the government due to their opposing opinions. Therefore, the migrants are usually only able to raise awareness on the policy proposals of Colombians abroad through maintaining the link with returnees and local organizations, or by taking initiative to meet with parliamentarian friends when traveling home. While the Colombian migrant collective is practically invisible as political subject, there is an extraordinary interest in them as income source. For this reason, the government runs a program from the national saving fund, in which Colombians abroad can invest their remittances to save for a house in Colombia (FNA, n.Y.). The interviewees recognize the efforts made in the 
right direction, as those types of investments can give women a certain degree of protection when returning from many years working abroad. However, this program is not sufficient, as it is not inclusive enough and there are hardly any opportunities for migrants to inform themselves about such alternative forms of transferring money home.

In sum, what is required by the public policies to improve the capacity of agency of Colombian migrants in Catalonia? To start with the individual level, it is fundamental to give them the necessary educational process to know about their rights and the existence of institutions that can facilitate their integration into the society. Only then it is possible to go beyond the private sphere, not staying stuck in the 'migrant image'. The interviewees also plead for easing the restrictive policies of the LEX, for facilitating the accreditation of degrees acquired abroad, and for penalizing private employers that abuse the migration conditions (e.g. by paying salaries under the minimum wage).

In the area of project work, the competition on scarce resources from the cooperation agencies should be avoided. Instead of fighting for funds, organizations should create a constructive dialogue in order to see what the common challenges are and enforce the collaboration to overcome them. Also, the cooperation agencies should be more (gender-)sensitive regarding the capacities of migrant organizations, because usually women migrant's cooperatives take longer to develop than local ones. Therefore, the funding plans should be adapted, granting them more and continuous money resources. And ultimately, women migrant's businesses should be offered a better support through the so called emprendeduría: an education format where migrants can learn how to run a business, to manage human relations within collective projects, etc. To acquire such management skills could be fundamental for migrant women in order to establish something lucrative and sustainable at the time of returning.

\section{Conclusions}

This research relates to three main academic and political fields within the MDN: the transnational activities of migrants, diaspora politics in conflict settings as a source for development, and the gender implications of migration. The article adopts a 
wide definition of development as well as transnational politics, to better display the diverse ways in which migrants are engaging in relation to their COO, COR and internationally.

It can be concluded that Colombian women are very active in maintaining a variety of links between Colombia and Catalonia, contributing to the emergence of a transnational social space that can have positive outcomes for the development of both countries. As many Colombians in Catalonia define themselves as victims of the armed conflict, their transnational activities have a strong political orientation. Hence, the most typical organized activity of Colombian women comprises the collection of testimonies from female victims residing abroad. Additionally, they are very engaged in building a network of support among fellow migrants. These findings go in line with the studies of Bermúdez (2010, 2016), as the women are very engaged in political and civic initiatives, although many of them are in disempowered positions (in some case, especially because of it).

Women migrants tend to have a better capacity of agency than in other recipient countries owing to the Catalan experience in applying gender-sensitive approaches to migrant policies and to conflict and peace. Nevertheless, organizations often lack financial support from above to officially engage in development projects. On the other side, the Colombian government is interested in their emigrant population when it comes to remittances, but usually ignores them as political subjects. This coincides with the analysis of Faist (2008), recalling that the transfer of political ideas often resembles a threat for emigrant governments.

The research shows that many women become limited in their political and socio-economic opportunities due to the LEX as well as a gendered labour market in Catalonia. Part of this reality is also that despite those circumstances, Colombian women are saving up a big proportion of their scarce resources to send them to their family home. However, this research concludes with the need to recognize their big value as fomenters of social change. They are not only money sources but possess of important human and political capital and are highly active as transmitters of social remittance. In this area, they have multiple roles as careers, educators, and peace advocates, which can contribute on the one side to the social transformation in Colombia and the harmonious cohabitation of locals and the migrant community in Catalonia. 
Finally, to promote their role as transnational agents of social change, it is very important that the migrant community has their human rights protected and is sufficiently supported by their governments when taking transnational action. For the Colombian government this means to create profound statistics of the emigrant population to better address the needs. Additionally, migrants need to be offered more information about existing programs. Further, a better education pedagogy should be applied to the communities that receive remittance. In the host region, it is crucial for migrant women to exert their citizenship equally to the opportunities local citizens have. Additionally, the Catalan society should be educated to not abuse the vulnerable migrant status when hiring women for domestic work. Regarding cooperation, the local agencies should offer migrant women more and continuous resources, as well as specific education formats for project work.

\section{Bibliography}

Agència Catalana de Cooperació al Desenvolupament (2015). Plan director de cooperación al desarrollo 2015-2018. Por un país comprometido con la igualdad de género y los derechos humanos, Barcelona.

Ayuntamiento de Barcelona (2018): Plan Director de Cooperación para la Justicia Global de Barcelona 2018-2021. Barcelona.

Basch, L., Glick Schiller, N. \& Szanton Blanc, C. (eds.) (1994): Nations Unbound: Transnational Projects, Postcolonial Predicaments and Deterritorialized Nation-States. Switzerland: Gordon and Breach.

Bermúdez, A. (2010). Transnational Political Practices of Colombians in Spain and the United Kingdom: Politics Here and There. In: Ethnic and Racial Studies 33 (1), 75-91.

Bermúdez, A. (2016). International Migration, Transnational Politics and Conflict: The Gendered Experiences of Colombian Migrants in Europe. London: Palgrave Macmillan.

Brinkerhoff, J. (2011). Diasporas and conflict societies: Conflict entrepreneurs, competing interests or contributors to stability and development? Conflict. Security \& Development 11 (2), 115-143.

Colombia Nos Une (CNU, n.Y.). Primer encuentro para la conformación de la mesa nacional de la sociedad civil para la migración, Retrieved July 29, 2019 from https:// www.colombianosune.com/mesa-nacional-sociedad-civil/como-vamos

Corporación Humanas (2012). Mujeres migrantes: Sueños y realidades. Aportes para un debate desde los derechos Humanos. Bogotá.

Cuentas Ramírez, S. \& Vera, P. (2011). Migración, Género y Desarrollo: Mujeres transnacionales actoras del cambio social. Barcelona: Diáspora Solidaria; Intered Catalunya.

Dannecker, P. \& Sieveking, N. (2009). Gender, Migration and Development: An Analysis of the Current Discussion on Female Migrants as Development Agents. COMCAD Working Paper (69).

De Haas, H. (2012). The Migration and Development Pendulum: A Critical View on Research and Policy. In: International Organization for Migration: International Migration (50). Genf: IOM. 8-25. 
Faist, T. (2008). Migrants as Transnational Development Agents: An Inquiry into the Newest Round of the Migration-Development Nexus. In: Population, Space and Place 14, 21-42.

Faist, T. \& Fauser, M. (2011). The Migration-Development Nexus: Toward a Transnational Perspective. In: Faist, T., Fauser, M. \& Kivisto, P. (Eds.): The Migration-Development-Nexus: A Transnational Perspective. Migration, Diasporas and Citizenship Series. Palgrave Macmillan. 1-28.

Fondo Nacional de Ahorro (FNA, n.Y.). Colombianos en el exterior. Retrieved June 25, 2019 from: https://www.fna.gov.co/colombianos-en-el-exterior

Guarnizo, L. (2008). Londres Latina. La Presencia Colombiana en la Capital Británica. México City: Universidad Autónoma de Zacatecas and Miguel Ángel Porrúa.

Hochschild, A. R. (2000). Global Care Chains and Emotional Surplus Value. In Hutton, W. and Giddens, A. (eds.): On The Edge: Living with Global Capitalism, London: Jonathan Cape. Insituto Nacional de Estadística (2019). Población por país de nacimiento, edad (grandes grupos de edad) y sexo. Retrieved July 18, 2019 from: https://www. ine.es/jaxi/Datos.htmpath=/t20/e245/p04/provi//0/\&file=0ccaa004.px

Las Americas (7.03.2019). La brecha de género entre los remitentes de remesas digitales a Colombia se cierra por un $50 \%$. Retrieved August 2, 2019 from: https:// www.diariolasamericas.com/economia/la-brecha-genero-los-remitentes-remesas-digitales-colombia-se-cierra-un-50-n4173378

La Colectiva de Mujeres Refugiadas, Exiliadas y Migradas (2018). Rompiendo el silencio desde el exilio - aportes para la memoria y la construcción de la paz con enfoque de género. Colombia.

Levitt, P. \& Nyberg-Sørensen, N. (2004). The Transnational Turn in Migration Studies. In: Global Migration Perspectives (6): Geneva: Global Commission on International Migration (GCIM)

Mayring, P. (2015). Qualitative Inhaltsanalyse. Grundlagen und Techniken. Weinheim: Beltz.

Ministerio de Trabajo, Migraciones y Seguridad Social (2016). Autorización residencia temporal por circunstancias excepcionales. Arraigo social. Retrieved July 26, 2019 from: http://extranjeros.mitramiss.gob.es/es/InformacionInteres/InformacionProcedimientos/Ciudadanosnocomunitarios/hoja036/index.html

Ramírez H., C. \& Mendoza S. L. (2013). Perfil Migratorio de Colombia 2012, Bogota: OIM Colombia.

Ratha, D. (2003). Workers' Remittances: An Important and Stable Source of External Development Finance. In Global Development Finance 2003: Striving for Development Finance. Washington D.C: World Bank 157-175.

Sen, A. (1999). Development as Freedom. New York: Anchor Books. Šribar, R. (2015). Glossary of common terms in gender equality and feminist theory, in M. Ule, Šribar, R. \& Venturini, A. U. (Eds.). Gendering Science: Slovenian Surveys and Studies in the EU Paradigms, Vienna: Echoraum. 173-191.

Van Hear, N. (2011). Diasporas, Recovery and Development in Conflict-ridden Societies. In: Faist, T., Fauser, M. \& Kivisto, P. (Eds.). The Migration-Development-Nexus: A Transnational Perspective. Migration, Diasporas and Citizenship Series. Palgrave Macmillan. 85-107. 